\title{
全球挑战与地方实践: \\ 将城市打造为包罗万象的生态系统 \\ GLOBAL CHALLENGES, LOCAL SOLUTIONS: \\ THE CITY AS AN ECOSYSTEM OF EVENTS
}

McGregor Coxalli计事务所董事、城市设计总监
Tom RIVARD
Associate and Urban Design Lead at McGregor Coxall
PO Box I083, Manly I 655, NSW, Australia
tom.rivard@m gregorcoxall.com

McGregor Coxall设计事务所的生物都 市主义

城市建设行为的首次出现以及民间流传 的城市起源, 大约可以追溯到 10000 年前的 沙漠中: 一只手伸出来, 将一把谷物放人另 一个人的手中。随着时代向后推移, 工艺和 技术诞生, 同时还额外催生出两个奢侈的元 素: 时间和金钱一一时间促进了职业的多元
化, 比如写作、艺术、演讲和文明教育, 而 金钱令消费者拥有了更多的选择，工资报酬 渐渐不完全遵循按劳分配。信息交换与物品 交易间有时会存在竞争关系, 而城市即是二 者共同作用的产物。交易赋予实物价值，使 之商品化, 但前提是它必须是看得见、摸得 着的; 另一方面, 交换可以赋予某种关系一 个基本价值, 而这需要基于经验而非某种固 定的准则，因此关系不易被商品化。

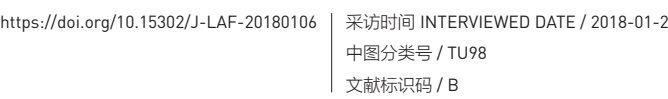

摘要

在这个全球危机四伏的时代，城市不仅是社会进步的载体，也是体现 多样性和灾难应对弹性的核心区域。面对日趋紧张的气候、社会、生态和 经济环境, McGregor Coxall设计事务所更关注人们建造自己城市的过程 和背后的故事。我们的项目对于这些指导城市建设的环境特性秉承辩证的 态度: 我们认同城市是经济增长的引擎和文化产业的市场, 但必须将建成 环境区别于 “自然” 的这种认知却未免荒谬。

当代城市的成就建立在全球发展和环境影响这两种压力相互矛盾的关 系之上。为解决二者带来的危机, McGregor Coxall设计事务所同时聚焦 于两种尺度下的设计实践: 着眼于区域范围内的经济发展和生态系统运作 的大尺度规划, 以及关于人、街道和街区的小尺度设计。系统性的设计思 想为我们的项目提供了经济和环境层面的实施框架, 而对社区需求的切实 考量则保证了我们能够为每个项目制定真正因地制宜的设计方案。

关键词

生物都市主义；弹性；绩效；公众参与; 叙事; 社区

\section{ABSTRACT}

In a time of global challenges, cities are critical not only as vehicles for progress, but also as centers of diversity and resilience. Confronted with intensifying climates, and social, ecological, and economic issues, McGregor Coxall focuses on the stories people tell in making their cities. Our projects accept and challenge these stories which underpin city-making: the engine of economic progress, the marketplace of cultural production, and the myth of our separation from "nature."

The success of contemporary city is built on a paradoxical relationship with two pressures: global development and environmental impacts. To address these crises, McGregor Coxall works at two scales, simultaneously, on all of our projects: in the large-scale realm of regional economic development and ecosystemic operations, and at the scale of the person, the street, and the neighbourhood. The systemic understanding provides the contextual basis by which projects perform, economically and environmentally, while our understanding of communities makes each project a genuine product of its time, place, and culture. KEY WORDS

Biourbanism; Resilience; Performance; Public Engagement; Narrative; Community

整理 田乐 汪默英

译 黄延峰 张晶宮

EDITED BY Tina TIAN Moying WANG

TRANSLATED BY Yanfeng HUANG Jingrui ZHANG 


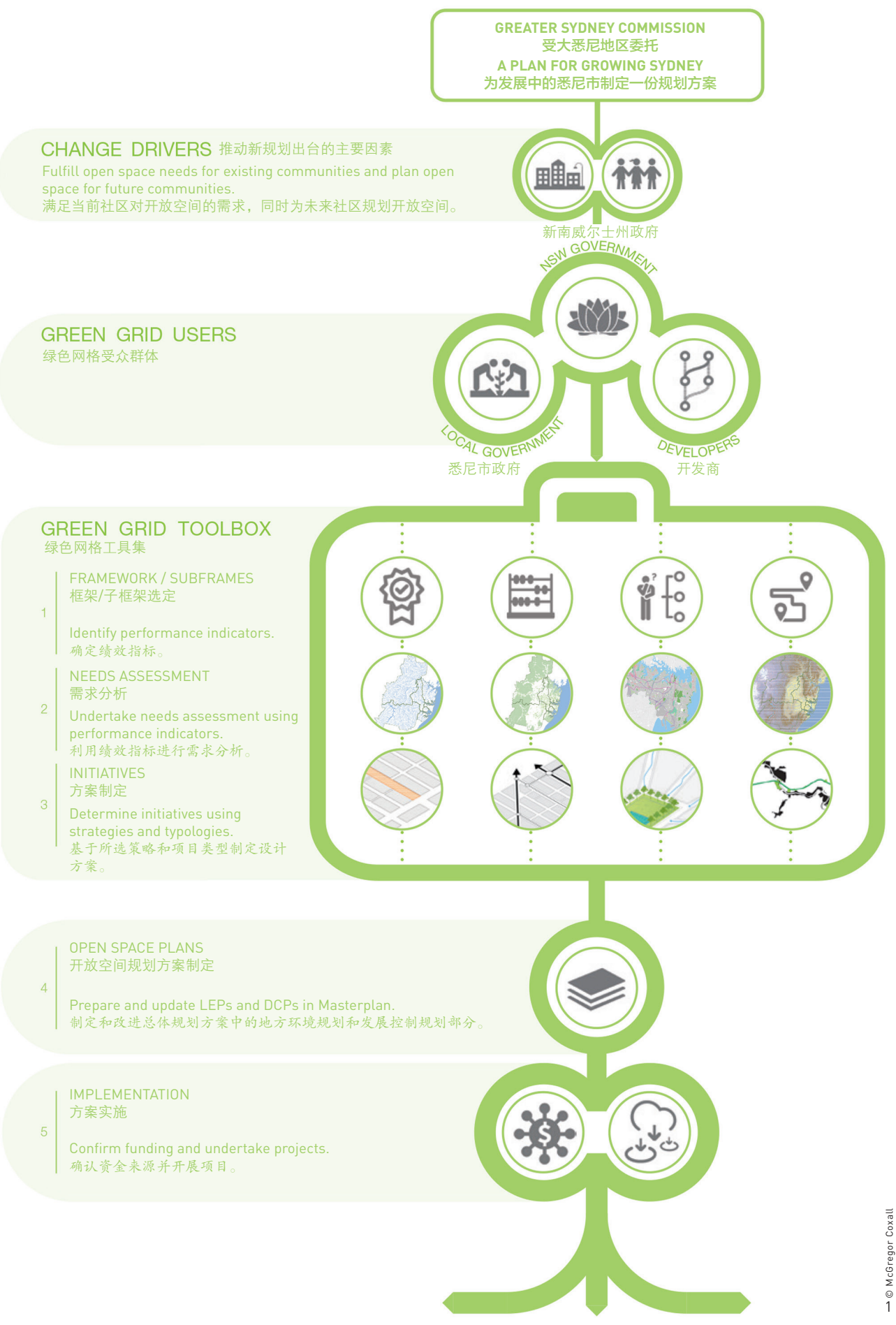

1. 创建绿色城市的方法论

A methodology for greening cities
这是一个社会、经济和生态解体的时 代, 这一点在城市中体现得尤为明显, 不 过, 城市是人类出现以来创造出的最大和最 成功的产品。正是由于城市在经济、文化和 社会上取得了成功, 它不仅成为了社会进步 的载体, 也是体现多样性和灾难应对弹性的 核心区域, 其间汇聚了各种各样的商品、信
McGregor Coxall设计事务所专注于待建场所所 展现的当地情况和设计思考。如果我们将城 市当成理想化的设计对象来建造, 它们就成 了用于消费的人造事物，而非体验的场所。 我们的项目对于这些指导城市建设的环境特 性（无论是 “自然的” 还是 “人工的” ) 秉 承辩证的态度: 我们认同城市是经济增长的 引擎和文化产业的市场，但必须将建成环境 区别于 “自然” 的这种认知却未免荒谬。这 种区别化会造成环境的不可持续性，因而成 为了城市面临的第二个有形威胁。

当代城市所取得的成就冊庸置疑，但这 些成就是建立在全球发展和环境影响这两种 生存压力的矛盾关系之上的。城市的多样性 吸引了国际资本，这些资本最终转化为一种 使城市趋于同质化的力量，抹去了场所独一 无二的鲜明特色，破坏了当地的生态和文化 特质。而来自环境可持续性的挑战亦是城市 发展的另一项产物：一方面，城市中公共交 通、共享设施，以及公共功能空间和设施的 密集分布导致城市生态足迹少之又少; 而另 一方面，过时的生产、基础设施和交通体系 下的贫富差距亦使得城市对当地和全球环境 的影响不断加剧。

这个星球正在不断城市化, 因为城市 是财富、创新和创造力的主要载体, 城市居 民、工人和游客以他们丰富的技能、知识和 文化创造了城市。如果说城市是人类制造的 最大实物, 那么它也是我们所掌握的关于城 市的所有知识的来源和宝库。这种信息的保 存、获取和共享对当代的都市主义和未来的 城市发展至关重要, 如果可以使信息的获取 和利用变得更为容易，我们就能从其中得到 构思、建造和管理城市所需的所有信息。

城市是一个复杂的生命体。与其他的复 杂有机体一样，城市面临的挑战也同样错综 复杂: 如何平衡全球发展和地方发展; 如何 协调资源共享和生态系统改善; 如何确保技 术和信息的所有潜在效益都可被应用于提高 民生福祉。

为了应对这些挑战, McGregor Coxall设 计事务所同时聚焦于两种尺度下的设计实 践: 着眼于区域范围内经济发展和生态系统 
运作的大尺度系统化、信息化设计, 以及关 于人、街道和街区的小尺度感知层面设计。 我们所有的调查和假设都基于严谨的方法论 与多学科的全面分析和交流; 基于对实操性 的充分重视, 我们得以确保项目从一开始就 尽可能地将各个维度的标准纳人考量, 以使 产出效果最优化。这些分析和交流的过程往 往会用到信息管理和基础设施建造方面的先 进技术, 这也是我们得以继续建设城市未来 的新工具。

系统性的设计思想为我们的项目提供了 经济和环境层面的实施框架, 而对社区及其 居民的需求和愿望的切实考量则保证了我们 能够为每个项目制定真正因地制宜的设计方 案。我们不是设计师; 我们是发现者、转译
者、谱写者。最后, 我们的项目仅聚焦三件 事情: 我们在当地发现了什么, 我们带去了 什么, 以及我们在那里建造了什么。

本文旨在探讨如何在城市建设过程中构 建真正适合当地商业、文化及生态环境的城 市弹性。McGregor Coxall设计事务所的设计 项目同时展现了可持续市场、文化多样性, 以及自然和人工生态系统的重新整合, 不仅立 足于本地, 还兼顾了不同尺度上的干预效果。

\section{绿色网格项目一一用于设计开放空间的 城市工具集}

作为城市可持续发展的一种重要工具, 绿色网格项目是一个致力于改善和整合大悉
尼都市区开放空间的项目。绿色网格聚焦 于为开放空间的设计过程构建一个集数据 分析、标准编目和图形交流于一体的综合 框架。该项目的最终目标是建立一个高品质 的开放空间网络, 包括国家公园、区域公园 和地方公园等多个尺度, 涵盖港口滩涂、 湿地、河流、海滩和小溪, 以及游乐场、运 动场、高尔夫球场、公墓和校园等各种空间 类型。

地方政府和GIS制图分析的数据分析表明 大悉尼地区缺乏开放空间资源, 同时也确定 了待开发的开放空间资源 (包括铁路地役权 属地、教堂院落、溪流地役权属地等)。该 项目利用这些GIS参数和数据分析揭示了哪些 区域需要开放空间, 以及需要什么类型的开
ENHANCE ECOLOGICAL VALUES 提高生态价值

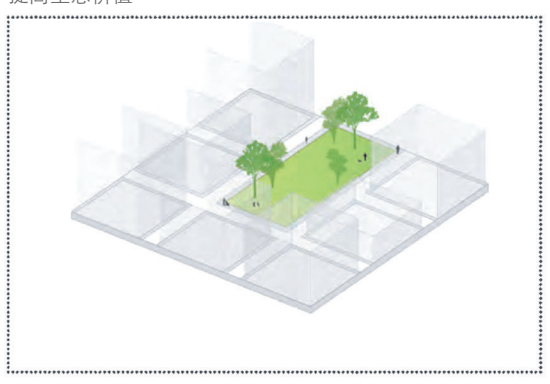

ALIGN PARK BOUNDARIES WITH STREETS 依据街道边界框定公园边界

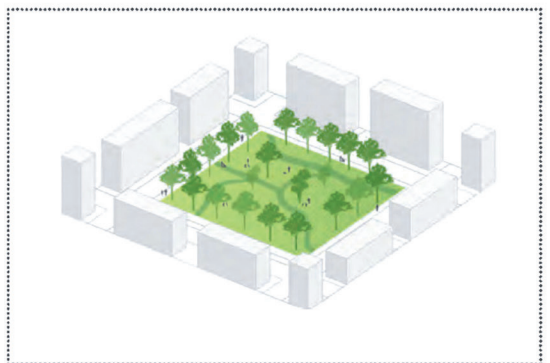

DEPLOY INTEGRATED WSUD INITIATIVES 应用水敏性城市综合设计方究

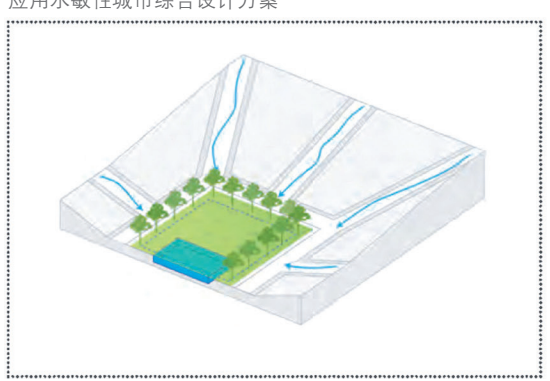

CLUSTER SPORTS SPACES 运动空间集合化

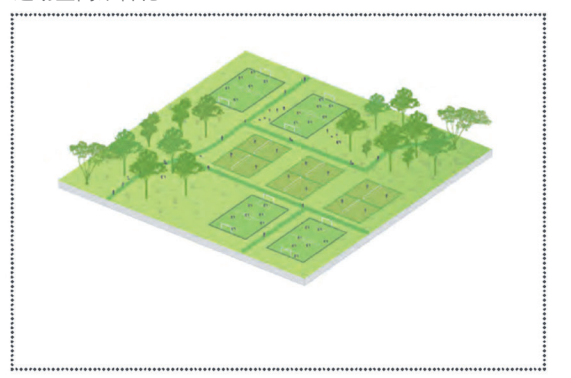

MAXIMIZE CENTRALIZED PARK SPACE 尽可能集中布置公园空间

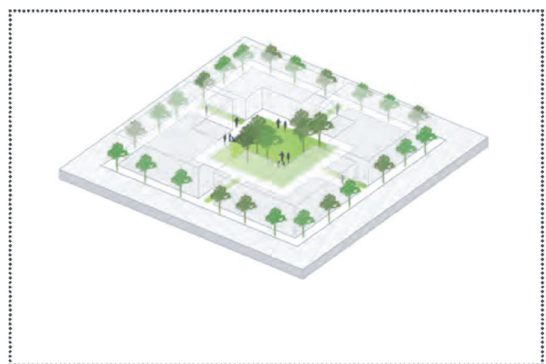

ENSHRINE SOLAR ACCESS TO PARKS 保障公园日照

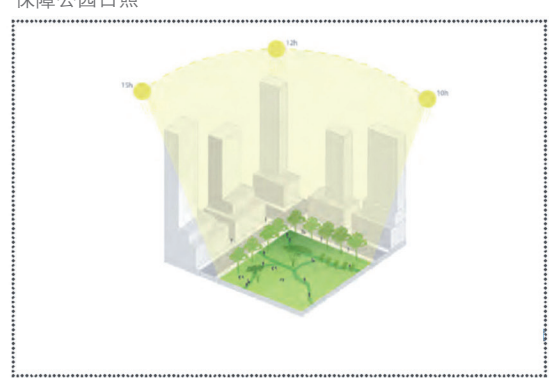

OPTIMISE INFRASTRUCTURE LANDS 优化基础设施用地

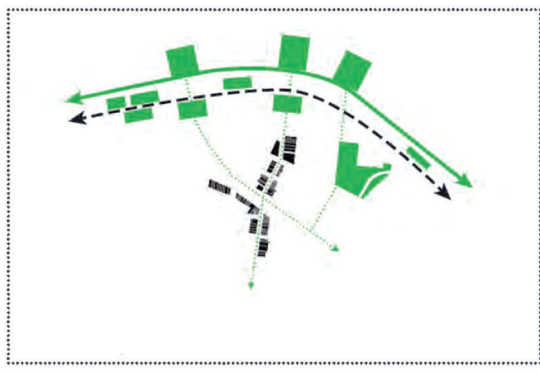

REGENERATE WATERWAYS

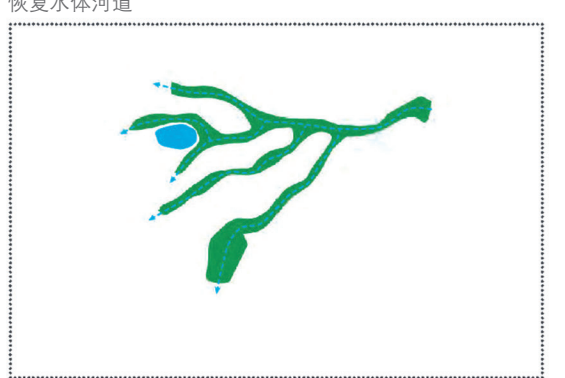

DEPLOY DIVERSE TYPOLOGIES 应用不同类型的公共空间

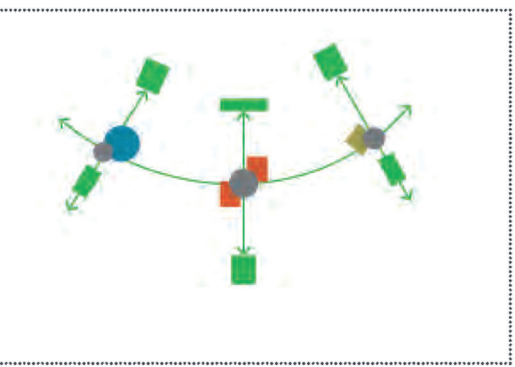

ACTIVE TRANSPORT NETWORKS 高效的通行网络

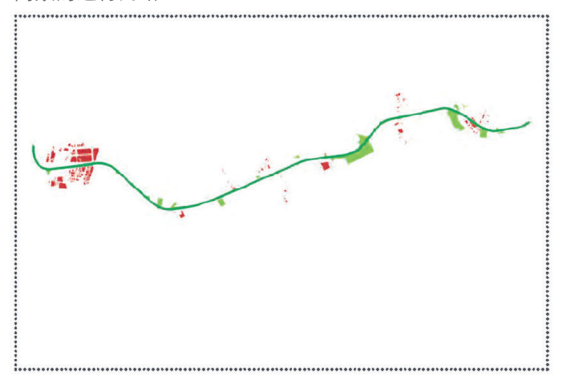

LINK TRANSIT HUBS

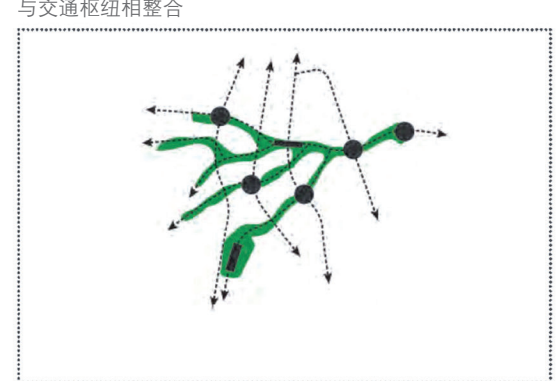

SHARE SCHOOL YARDS

共享校园

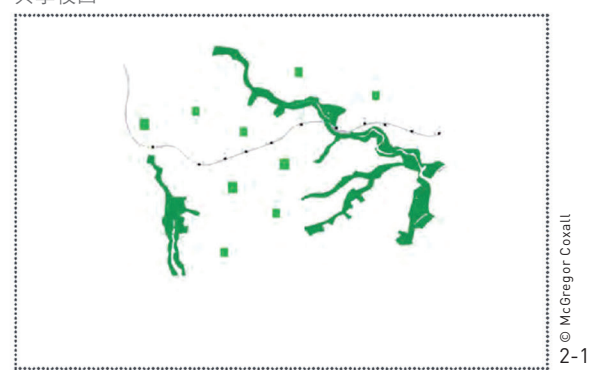


2. Strategies to link green spaces across the city and to create more public amenities.
放空间。同时, 利用地址点数据对各郊区的 人口统计特征进行逐一分析, 以对这些开放 空间设计加以精确调整。

通过强化溪流流域、交通地役权属地、 人行道和自行车道, 可实现开放空间和绿地 之间的连通性。而随后引入的拟建的绿色空 间和社会人口驱动元素则为地方政府和其他 相关机构确立了一个优先层级框架, 并为基 础设施建设提供了一整套工具集。除了提供 更多的开放空间外, 绿色网格项目还希望明 确且尽可能地满足当地在空间和运营上的需 求, 不仅要增加公共空间的数量, 还要增强 其可达性和实用性。

在McGregor Coxall设计事务所看来, 绿 色网格是将政策转化为实践工具, 其构建了
一个连接市民和开放空间的生态系统, 创建 了更加绿色、更具社会凝聚力和生物多样性 的城市环境。如此一来, 它成为了一套可以 应用于任何城市、任何尺度的工具集。

\section{大脑売山森林公园一一深圳核心生态旅 游胜地}

大脑壳山险峻的地质特征构成的野生景 观展现了当地的原始森林地貌和古老生态环 境, 这种独特的景观为项目提供了类型多样 的自然环境和颇具诗情画意的设计本底。大 脑壳山森林公园地处深圳市中心, 是连接城 南城北两个区域的门户，站在山顶可俯瞰深 圳的城市全貌。大脑壳山的主要生态系统基
本完整, 囊括了丰富的动植物栖息地种类。 然而，城市基础设施的引人对环境造成了严 重影响, 包括沿山脊架设的高压线、山脚的 水库, 以及高速公路等主干道等, 将大脑壳 山及其栖息地与附近的银湖山和亚寄山相割 离。在认识到问题的严重性及自然资产对城 市的重要性之后，龙华区区政府与深圳市城 市规划和土地资源管理委员会于2017年联合 举办了一场国际设计竞赛，以为这一位于深 圳中心地带、占地约 $500 \mathrm{hm}^{2}$ 的山地公园征集 总体规划方案。

McGregor Coxall设计事务所的设计方案 被选为该竞赛的两个优胜方案之一, 得以继 续进行深化设计。该方案兼顾了城市开放空 间的舒适度及对生态环境的保护和改善，解

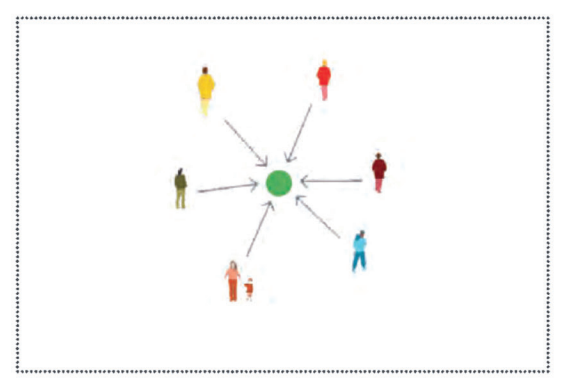

SHARE PRIVATE FACILITIES 共享私有设施

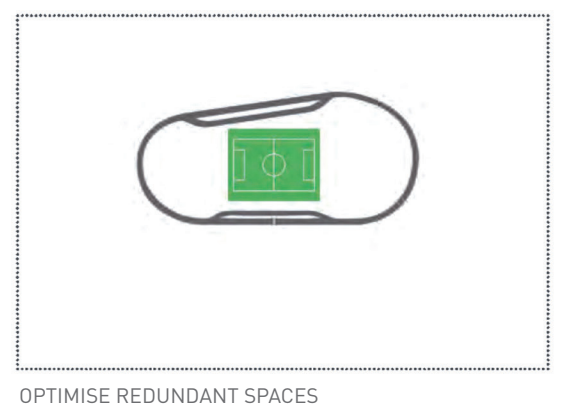

OPTIMISE RED
改善冗余空间

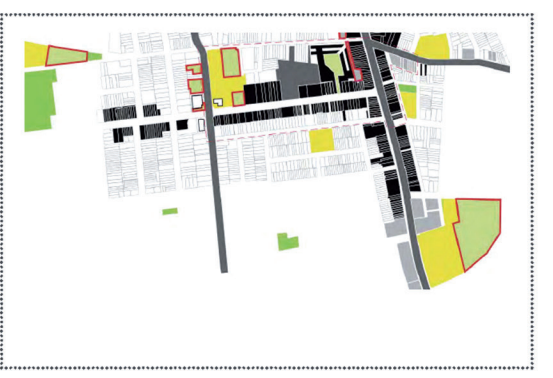

CREATE COMPLETE STREETS 创建功能完善的街道

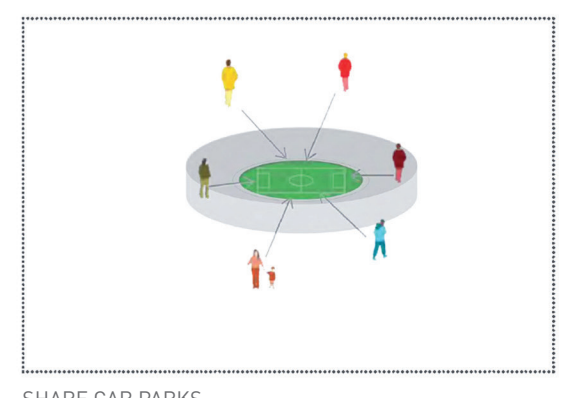

SHARE CAR PARKS
共享停车场

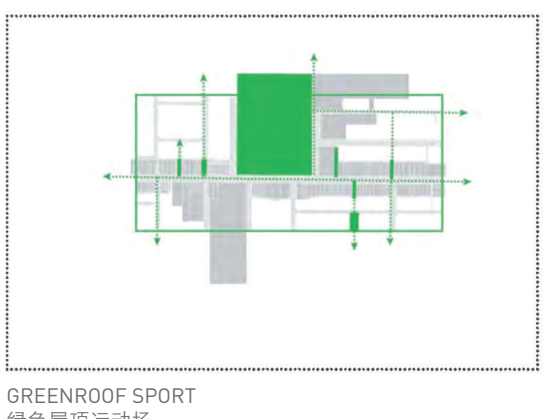

GREENROOF SPO

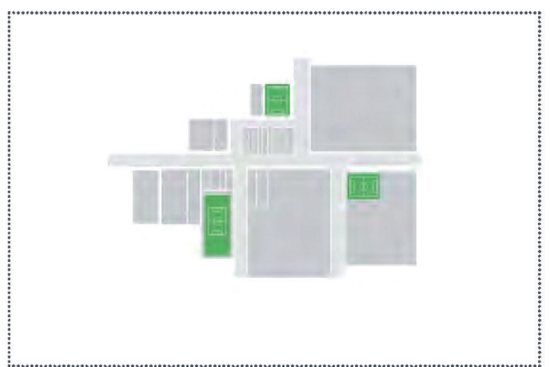

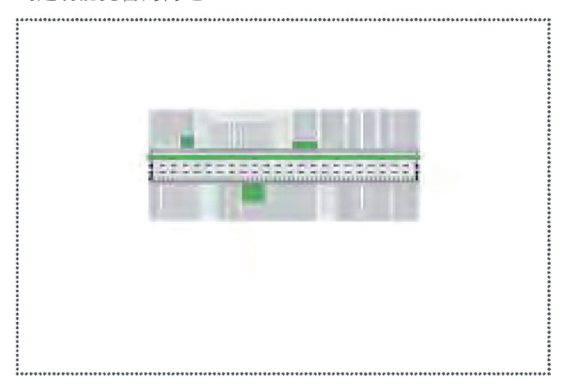

ACTIVATE URBAN CENTERS 激活城市中心

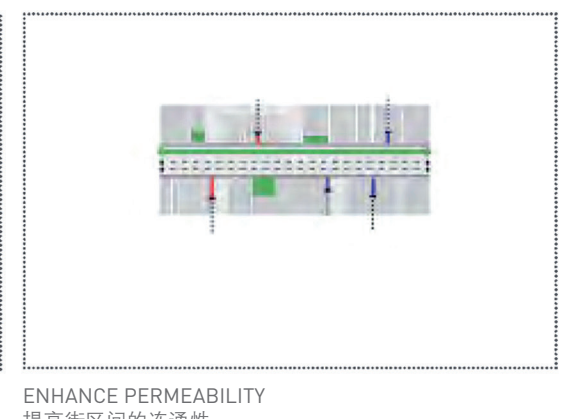

ENHANCE PERMEABIL

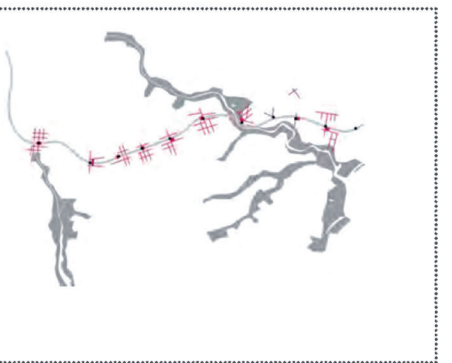

AMPLIFY ENDEMIC CHARACTER 强化地方特征

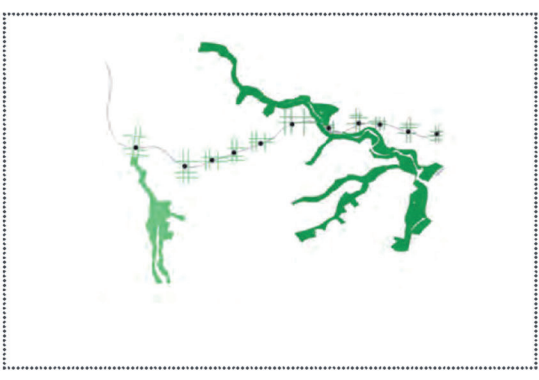

MAXIMIZE URBAN FOREST 尽可能增加城市林地空间

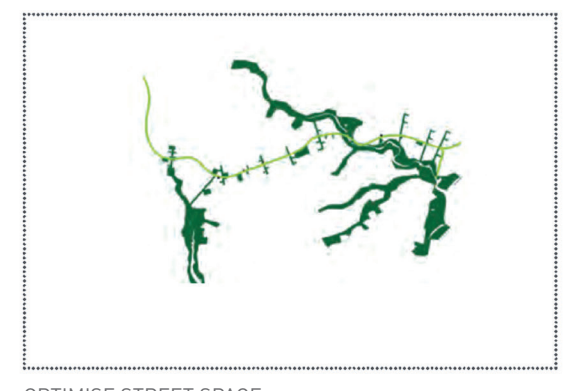

PTIMISE STREET SPAC

化街道空|目

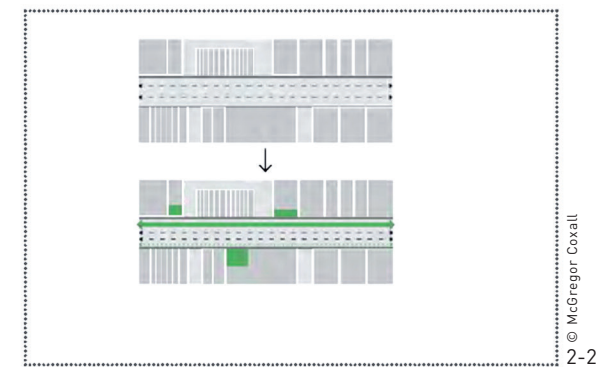




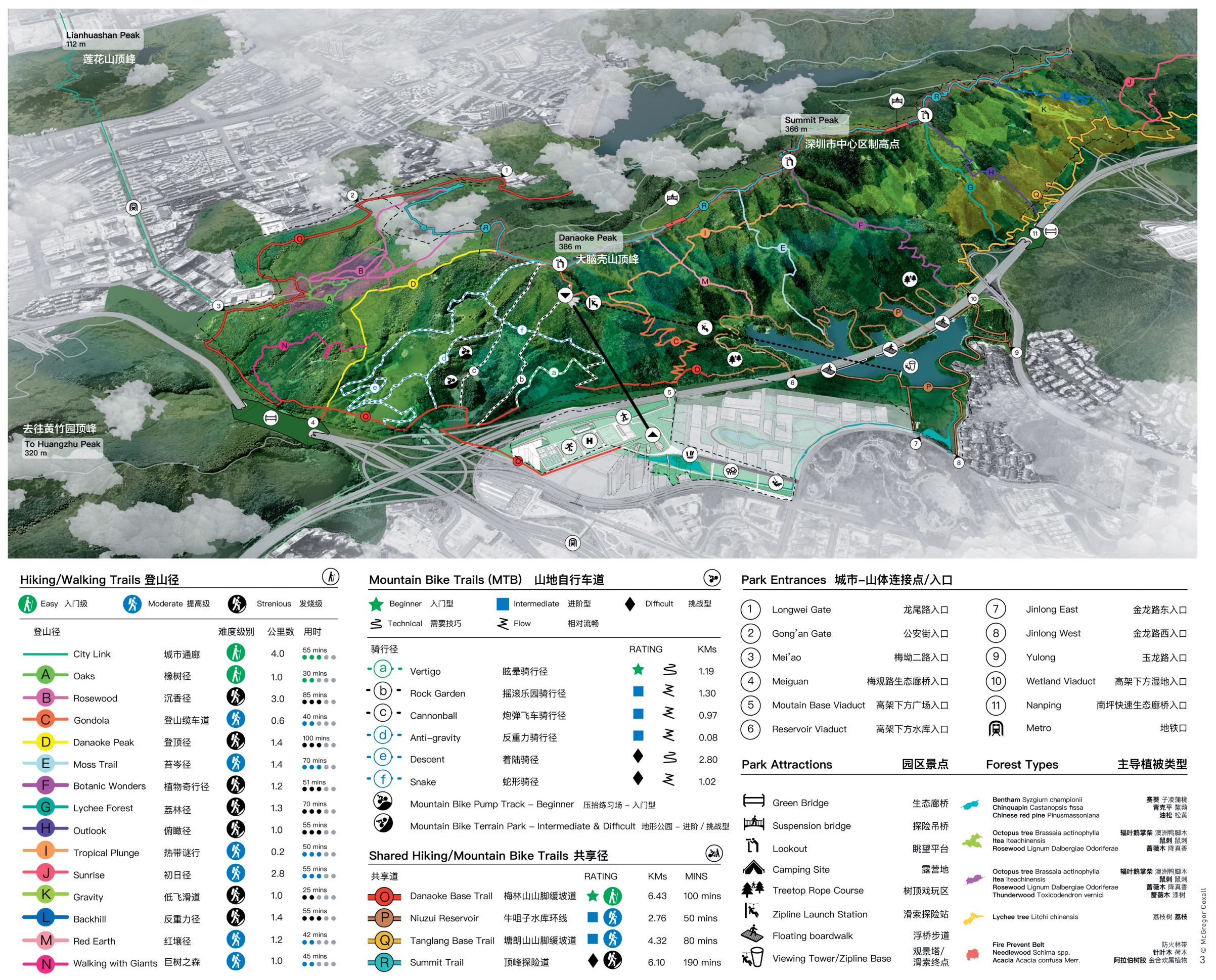

决了场地现有问题并为其创造了新的机遇 总体规划提出了 “公园大三角” 的核心设计 理念, 将大脑壳山、黄竹园和莲花山这三座 位于城市中心地带的雄伟山峰串联起来, 共 同形成城市的文化轴线。此外，总体规划方
案还将环境设计、工程技术及市政设施与场 地及周边的科技园区和高密度城区的水管理 系统相整合。

公园核心区以大脑壳山山体为主, 设有 大脑壳山活动中心、公园管理总部、体育公
园和城市公园, 在城市环境中创建了多种活 动场地和娱乐设施。其中, 活动中心可为各 类文娱活动提供场地。到了夜晚, 餐厅、咖 啡馆、酒吧和商店活力四射, 运动活动、现 场音乐表演、自行车炫技和其他令人惊叹的
3. 大眩壳山森林公园规划 方案

3. Master plan for Danaoke Mountain Park 
景象轮番上演。而这里的建筑也运用了太阳 能光伏玻璃和被动式通风系统等先进的可持 续性技术。

方案提出的海绵城市建设措施包括引 人湿地、城市湿塘和水敏性城市设计系统, 这些元素能够收集场地中所有的城市雨水径 流, 经生物过滤后可再利用为建筑与景观灌 溉用水。此外, 收集到的水资源在经过处理 后集蓄于位于山脚处的中央水库中, 以备再 次利用, 溢流则被引流至一条在人园主路旁 后期开丵的小溪之中。公园内的所有水系统 都与该区域内更大尺度的水网相连。

大脑壳缆车的建造可使观光客、步行 者、登山者和山地车自行车骑行爱好者直达 $360 \mathrm{~m}$ 的高峰之上。不仅如此, 公园还提供了 包含长逾 $40 \mathrm{~km}$ 的步行和登山路线的游道网 络, 并设有 20 余种不同的步行和登山线路, 以供游人体验深圳的旖旅风光。缆车的山顶 车站设有森林滑索, 可以从 300 多米高的密 林深处直接滑至湖面上空。游道网络沿线设 有一系列景点, 包括露营地、吊桥、高空栈 道、休息处和观景台。此外, 公园还设有长 达 $5 \mathrm{~km}$ 的山地自行车俯冲道, 游客可以从这 一极具冒险趣味的设施中获得难忘体验。由 废弃的高速公路建设区改造而来的山地自行 车公园为不同年龄段的使用者创建了一个共 享空间。

最后, 该项目对本地栖息地进行了有 机整合, 并通过架设一系列路桥, 缝合了原 本被割裂的山脉, 促进了生态休闲活动的开 展, 同时提升了区域可达性、城市服务设施 和环境绩效。该项目是McGregor Coxall设计事 务所对结合了景观、都市主义和环境科学的 跨学科研究方法进行综合运用的典型范例。

\section{智慧城市一一创造新一代的适应性城市 空间}

如今, 信息技术的发展步伐日益加快。 在智慧城市运动的背景下, 这意味着我们能 够利用数据创造出更具适应性、连通性、可 持续性, 以及更加健康的人类栖息地。随着 居住环境与社区健康之间的联系愈发紧密,
如何以智慧城市相关技术的发展来回应人类 这一最为复杂的变化之物的需求也变得更为 迫切。

公共空间的重要作用体现在它能够最大 限度地增加人与人之间接触的机会、有助于 社区发展, 以及创造灵活使用空间。当前的 技术革新不仅为设计建造高效运作的城市提 供了机会, 同时还为赋予社区居民更多的公 共空间所有权提供了实体和数字化平台, 城市的健康指数和可持续性亦得到了提 升。此外, 迅速的全球人口城市化迫使我 们对传统开放空间进行重新解读, 以协助 我们在现有城市结构的基础上, 构建能够 提供灵活的新型解决方案、创造更多机遇 的 “新大陆”。

McGregor Coxall设计事务所提出的智慧 城市计划是英国研究小组的智慧结晶。这一 计划融合了现有技术与新兴技术, 并就公共 设施在城市中扮演的角色展开探讨, 力图在 更大的城市背景下推动变革, 并营造出未来 的公共空间。

作为伦敦智慧城市设计竞赛的优胜方 案, “智能地毯”项目开发了一种使用者需 求响应型互动界面, 通过一系列铺装模块将 街道转变为能够生产能源、提供照明, 以及 进行感官识别和实时分析的多功能智能系 统。“智能地毯”的设计原型将于2018年在 伦敦建筑节上展出。

“你好, 克罗伊登!”项目通过提出 一系列具有适应性的组件, 来创建装置、标 识牌、种植池等社会基础设施。在实境增强 应用程序的帮助下, 社区居民可以利用这些 元素对自己社区中的公共空间进行个性化设 计。为了保障社会和环境的可持续发展, 每 个社区的基础设施组建将依照其具体区位环 境和居住于其间的不同社群，采取具有针对 性的组合方式。该项目目前已得到克罗伊登 市议会的大力支持。

“会呼吸的房间” 项目将城市公共连 接/过渡空间视为可供试验未来建筑建造策略 的独特空间环境。在扩大绿色网络、街道和 公共空间的同时, 该项目旨在激活那些原本 处于闲置状态的中性空间, 使之在城市结构
中, 以及在环境、社会和文化层面上发挥积 极作用。

\section{结语}

以上项目展现了McGregor Coxall设计事 务所如何将对自然生态系统及其需求的深刻 理解整合到城市及区域发展的现有模式和新 兴模式中。如何使人造生态系统与自然和谐 共生、互通共融, 并成为一个有机整体, 是 我们 (以及所有在城市中工作或从事城市设 计相关行业的人员) 当前正面临的挑战。

我们期望通过了解城市系统及栖居于其 间的居民所具有的所有复杂特性, 从而发掘 城市潜在的资源和需求。基于这些发现, 我 们构建了物质空间连通网络和通讯网络, 以 在空间、信息、社会、环境、经济或文化等 各个层面创造机遇。在这个过程中, 我们鼓 励各个年龄段的所有利益相关者和城市居民 全方位地参与到我们各种类型的项目 (如公 共空间、公园、城市步行街、街道、院落、 区域经济体、国家生态系统等) 之中, 与设 计产生互动, 并在设计过程中享有一定的自 主权。

McGregor Coxall设计事务所与合作伙伴 建立了明确的目标实现战略框架, 包括随着 城市、政府、社区和所有利益相关者的需求 不断变化, 资源储量不断积累, 如何保障项 目的长期发展一一这一工作框架在我们的所 有项目中均有体现。McGregor Coxall设计事务 所为每个项目提出的设计方案都为项目所在 地及其周边地区自身的资源和预期描绘出清 晰而美好的未来蓝图, 同时保护并延续每一 个场地的独特性, 创建出一处处秀美山川、 一座座景观之城、一个个充满活力又丰足富 饶的社区。LAF 


\section{McGregor Coxall's Biourbanism}

The first act of urbanism, the apocryphal birth of the city, took place some 10,000 years ago, in the desert: one hand reaches out and deposits a handful of grain into another waiting palm. This surplus, born of technology, produces two other luxuries: time (which allows diverse practices - writing, art, discourse, and civilisation itself), and money (allowing consumer choice, a separation between one's labour and its rewards). The city is a product of these two sometimes competing agendas - the exchange of information and the transaction of goods.

Transactions put a value on a material object, commodify it, requiring that it be present and tangible. Exchanges, on the other hand, place a primary value on a relationship, demanding experience, which cannot be easily commodified.

This is a time of social, economic, and ecological unravelling, especially in cities, the largest and most successful products of human existence. Precisely because of their economic, cultural, and social success, cities become critical not only as vehicles for progress, but also as centers of diversity and social exchange, in a diverse range of goods, information, and capital. However, global and regional pressures, both climatic and economic, are intensifying, threatening both the physical and the social fabric of the city. In an increasingly globalized world, the erasure of the local by the international is a primary threat to the cultural uniqueness of cities.

McGregor Coxall focuses on the local conditions and considerations that places already offer in the making and re-making of our cities. If we create cities as idealised objects of design, they become artefacts of consumption, rather than sites of experience. Our projects both accept and challenge the narratives
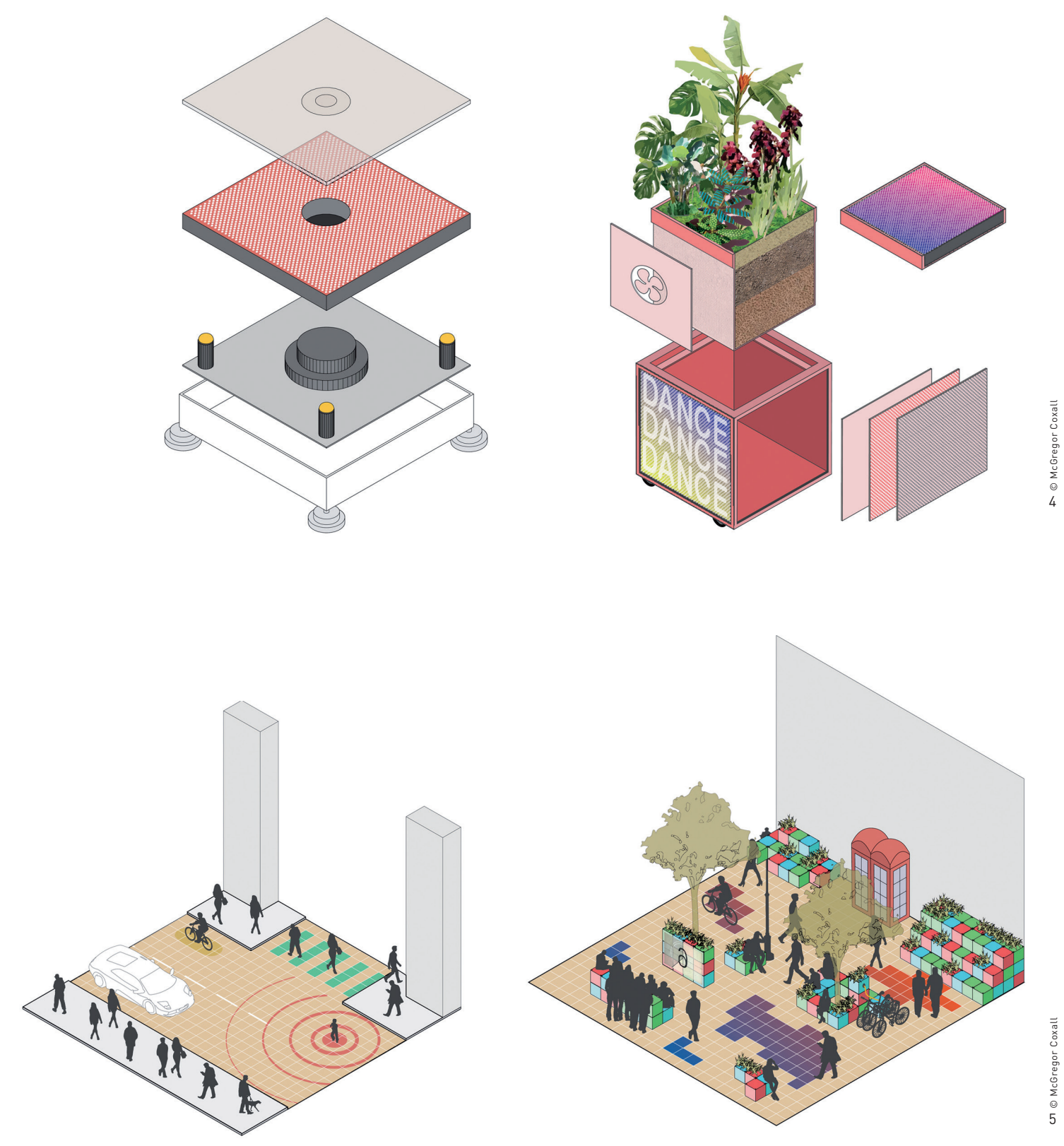

(both "natural" and "manmade") which underpin city-making: the engine of economic progress, the marketplace of cultural production, and the myth of our separation from "nature." This separation is the second tangible threat to the city environmental unsustainability.

The unquestioned success of contemporary city is built on a paradoxical relationship with these two existential pressures: global development and environmental impacts. The diversity of the city attracts global capital, which ultimately becomes a homogenising force, erasing unique and distinct precincts, and displacing local ecologies and cultures. The second challenge, that of environmental sustainability, is also a product of the success of our cities: while their density (with public transport, shared amenities, and common purpose) should allow cities to have 
4. “智能地毯” 项目: 鼓 励公众参与的基础设施 基于“智能地毯”技术

在城市中开展 “智能地 毯”项目

4. Smart Carpet: Infrastructure for civic engagement

5. Adaptable programs made possible by the Smart Carpet technology

6. Smart Carpet applied in urban design

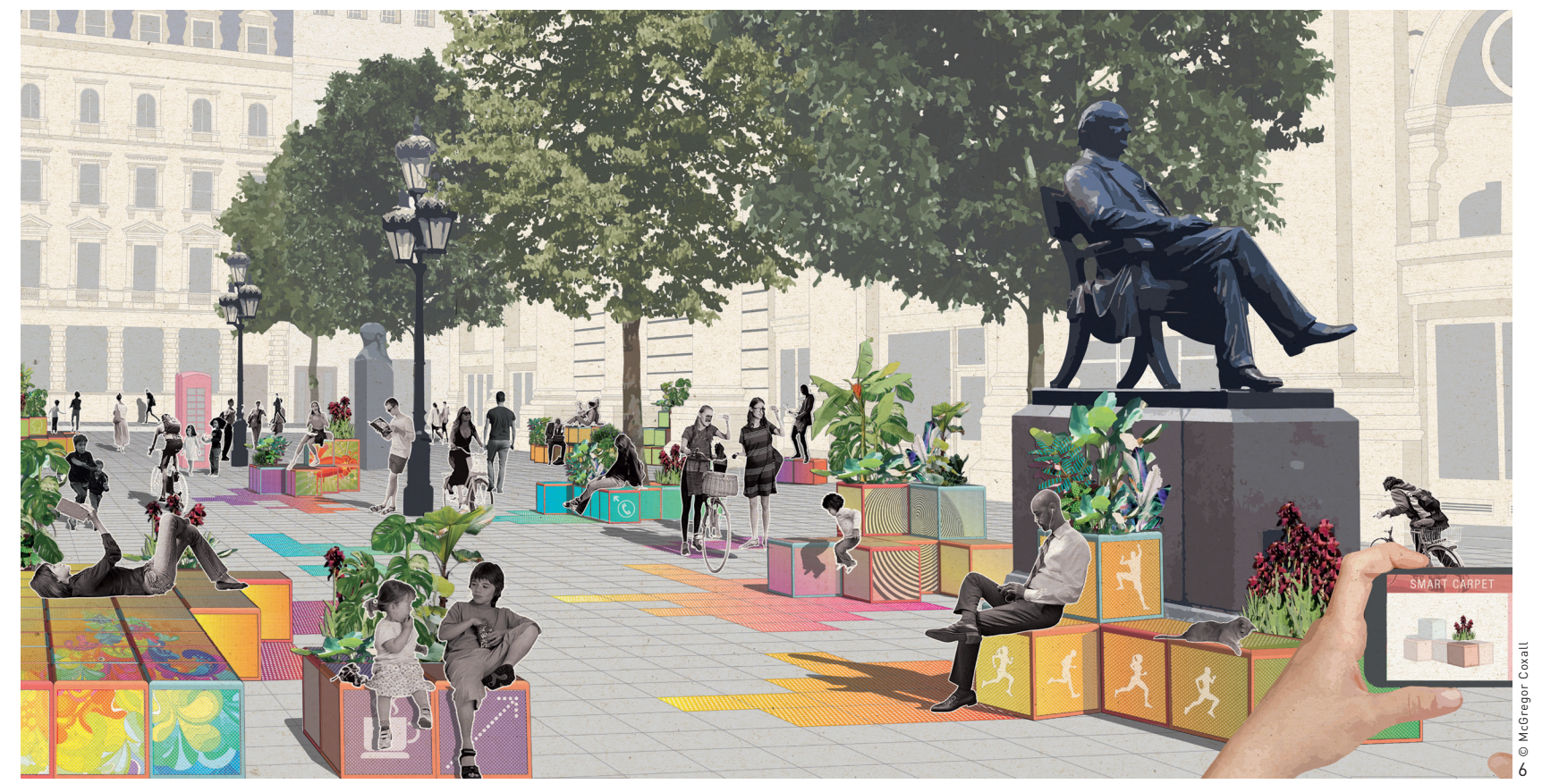

small ecological footprints, inequitable affluence supported by outdated systems of production, infrastructure, and movement only increases cities' environmental impacts, both locally and globally.

The planet has become urbanized because cities are the principal vehicles for the production of wealth, innovation, and creativity, generated by the diverse skills, knowledge, and cultures of their residents, workers, and visitors. If the city is the largest physical artefact produced by humanity, it is also the source, and the repository, of all the knowledge we hold about the city. The preserving, accessing, and sharing of this information is critical to contemporary urbanism and the city of the future - it allows for all the information we require in the conception, the manufacture and the management of our cities to be brought to bear - so long as we make it increasingly accessible and usable.

The city is a complex living thing.
And, like any complex organism, the challenges the city faces are equally complex: balancing global development with local evolution; harmonising resource sharing with ecosystem enhancement; and ensuring that all the available possibilities offered by technology and information are dedicated to the opening up of civic possibilities.

To address these challenges,

McGregor Coxall works at two scales, simultaneously, on all our projects: in the large-scale systemic and informational realm of regional economic development and ecosystemic operations, and at the experiential and tangible scale of the person, the street, and the neighbourhood. Overlaying all these investigations and propositions is a rigorous methodology of comprehensive multi-disciplinary analysis and communication, an operative lens by which we ensure our projects consider as many criteria as possible at the outset, and that the outcomes produced are delivered as expansively as possible. These processes of analysis and communication often demand leading technological applications, in both information management and physical infrastructure - novel tools with which we can continue to write the future of our cities.

Our systemic understandings provide the frameworks by which our projects perform, both economically and environmentally, while the close consideration given to the needs and desires of communities and their inhabitants provides the focus to make each project unique, identifiable, and a genuine product of its time, place, and culture. We are not designers - we are discoverers, we are translators, and we are composers. In the end, our projects comprise only three things: what we find there, what we bring there, and what we make there.

This article explores processes of city-making that establish genuine urban resilience in local systems, whether 


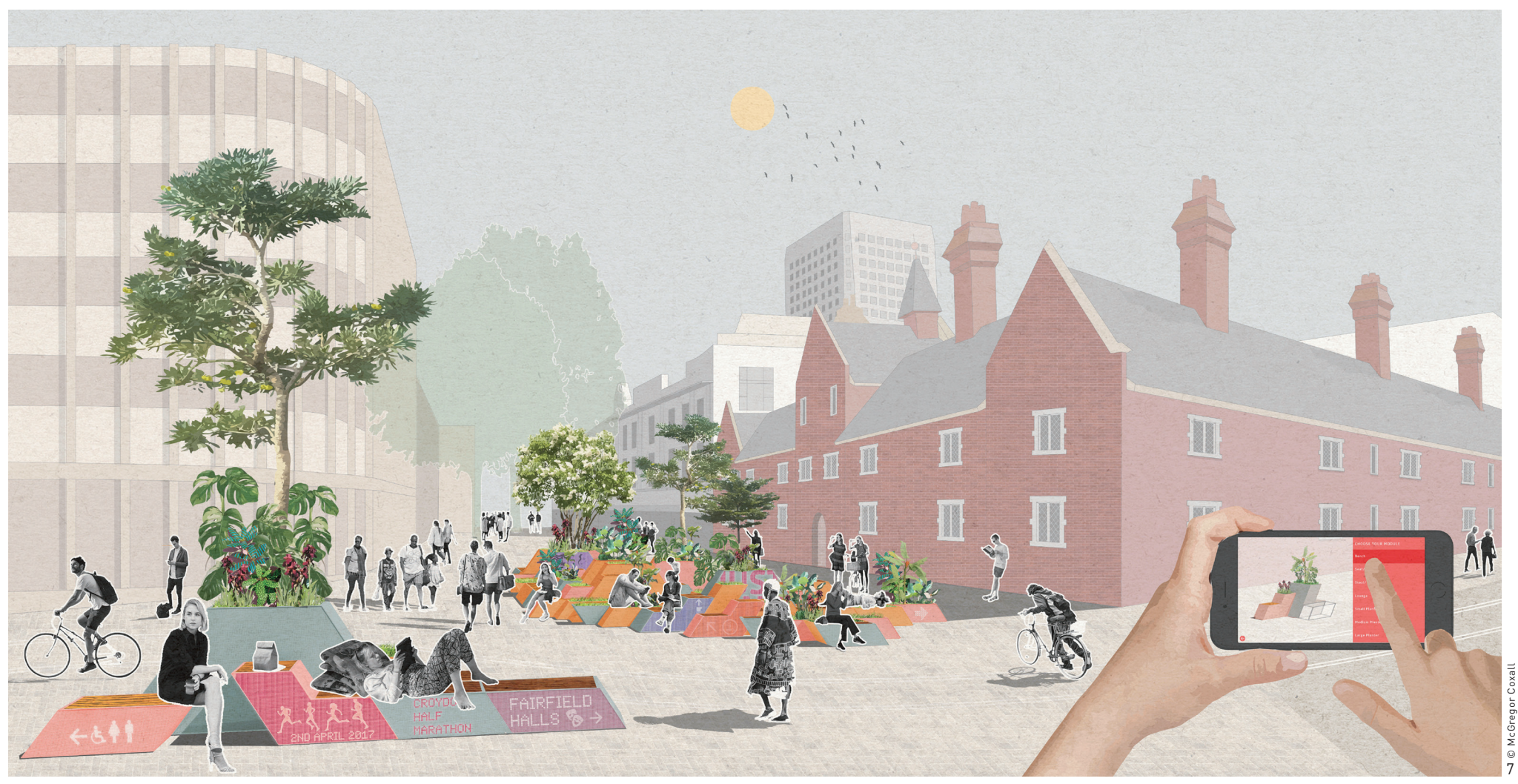

commercial, cultural, or ecological. It is illustrated by McGregor Coxall projects that combine sustainable markets, cultural diversity, and the re-integration of natural and man-made ecologies, creating places from the ground up, and delivering outcomes at many scales.

\section{Green Grid - An Urban Toolbox for Delivering Open Space}

The Green Grid, a key instrument in the sustainable development of the city, is a project dedicated to the enhancement, improvement, and integration of open space throughout metropolitan Sydney. The Green Grid focuses on processes of data analysis, criteria cataloguing, and graphic communication in constructing a comprehensive framework for open space delivery. The project's goal is the eventual creation of a network of high-quality open spaces, ranging from national, regional, and local parks, through harbour foreshores, wetlands, rivers, beaches, and creeks to playgrounds, playing fields, golf courses, cemeteries, and school yards.

Data analysis from local councils and GIS mapping illuminated residential areas across Greater Sydney deficient in open space resources, while also identifying potential unrealised open space resources (railway easements, church yards, creek easements, etc). The project utilised these GIS parameters and data scripting to reveal which areas needed open space, and of what type. Concurrently, individual suburbs were analysed using address point data to provide population demographics to fine-tune these open space offerings.

Interconnected linkages between open space and green areas were developed by enhancing creek corridors, transport easements, footpaths, and cycleways. The green spaces proposed and social demographic drivers were subsequently combined to establish a matrix of priorities and an infrastructure toolkit for local councils and other delivery authorities. Beyond the simple provision of more open space, the Green Grid project aims to clearly satisfy highly local spatial and operational demands, by not just increasing the quantity of public space, but also enhancing its accessibility and its utility.

For McGregor Coxall, the Green Grid is an instrument that turns policy into action to create greener, more socially cohesive and biodiverse urban environments in an interconnected ecosystem of city residents and open space. As such, it becomes a series of instruments that can be applied to any city, and at any scale. 


\section{Danaoke Mountain Park - Eco- Tourism in the Heart of Shenzhen}

The steep geology of Danaoke Mountain underlies a wild landscape of ancient forests and ecologies providing a range of natural environments and an idyllic backdrop. The Danaoke Mountain Park is the geographical heart of Shenzhen City and the gateway between the north and south districts of the city. Enjoying panoramic views over the city, the mountain's major ecological systems are primarily intact, harbouring networks of rich and diverse flora and fauna habitats. However, the encroachment of urban infrastructure has had significant impacts on the environment - these include high voltage lines along the mountain ridges, a water reservoir at the base of the mountain and major arterial freeways separating Danaoke Mountain and its habitats from the nearby Yinhu and Yaji Mountains. Recognizing these issues and importance of this natural asset to the city, the Government of Longhua District and Urban Planning and Land Resources Commission of Shenzhen Municipality jointly organised an international design competition in 2017, seeking master planning proposals for this $500 \mathrm{hm}^{2}$ mountain park in central Shenzhen.

McGregor Coxall was subsequently awarded as one of two winners to further develop the design. The proposal addresses existing issues and creates new opportunities by balancing the requirements for urban open space amenity with ecological enhancements and protection. The core masterplan concept proposes a "Parkland Triangle" which unites the three majestic mountain peaks of Danaoke, Huangzhu, and Lianhua at the geographic center of the city aligned to its cultural axis. The masterplan integrates a water management system combining environmental performance, engineered solutions, and civic amenity for the site as well as adjacent tech campus and surrounding high density.

The heart of the park lies the Danaoke Mountain Base containing the Mountain Base Hub, Park Ranger Headquarters, Sports Park, and Urban Park, offering a range of playground and recreation facilities in an urban setting. The hub is a vibrant home for an eclectic mix of activities and cultural events. At night restaurants, cafés, bars, and shops come alive with sports, live music, biking action, and stunning sights. Buildings utilise pioneering sustainability techniques including solar glass and passive ventilation.

The proposed Sponge City initiatives includes a wetland, urban pond, and Water Sensitive Urban Design (WSUD) system that collects all urban runoff from the site for bio-filtration and reuse in the buildings and landscape irrigation. Furthermore, water is treated and stored in a central reservoir under the hill for reuse, while overflow is guided into a reclaimed creek running alongside the major access route. All of these water systems link into the broader water network in the district.

The Danaoke Gondola lifts sightseers, walkers, hikers and mountain bikers to the $360 \mathrm{~m}$ high peak. Boasting a gondola accessed network of trails for walking and hiking of more than $40 \mathrm{~km}$, Danaoke Mountain park offers over 20 different walks and hikes for experiencing the stunning scenery of Shenzhen. The top station of the Gondola has a Forest Flyer Zipline that drops more than 300 meters over the forest to the lake below. The trail network has a range of attractions including camping sites, suspension bridges, raised boardwalks, rest points, and scenic lookouts. Adding to the adventure spirit of the park, $5 \mathrm{~km}$ of lift accessed downhill gravity mountain bike trails are provided. 
A Mountain Bike Terrain Park located on the disused motorway construction area provides a sharing place for all-age visitors.

Finally, the project stitches together the local habitats and promotes ecorecreation by providing a series land bridges over the freeways that separate the adjacent mountains. Concurrently improving local accessibility, urban amenity and environmental performance, the project is an exemplar of McGregor Coxall's integrated disciplinary approach, combining landscape, urbanism, and environment.

\section{Smart Cities - Creating the Next} Generation of Adaptable Urban Spaces

Developments in information technology are multiplying at an ever- accelerating pace. For the Smart City movement, this means leveraging data to create constantly adapting, increasingly connected, and sustainably healthier human habitats. As we identify stronger links between our environment and the health of our communities, the development of this technology increasingly needs to respond to the most complex parameters of all: people.

We understand the importance of public space to maximize human encounters, prioritise community outcomes, and provide flexible spatial opportunities. Current evolutions in technology offer the opportunity to not just engineer a more efficient city but to also provide physical and digital platforms that give our communities greater ownership over their public spaces, while improving the health and sustainability of our cities. Coupled with a rapidly urbanising global population, this demands a reinterpretation of traditional open spaces in favour of a new territory for innovative and flexible solutions creating new opportunities within the existing urban fabric.

McGregor Coxall's Smart City proposals are a product of our UK research think tank, hybridising existing and emerging technologies to expand our investigations into the role of civic tools to enable change within the greater urban context and create our future public domain.

"Smart Carpet," the winner of the City of London's Smarter Cities design competition, is an interactive surface that responds to users' demands. A series of

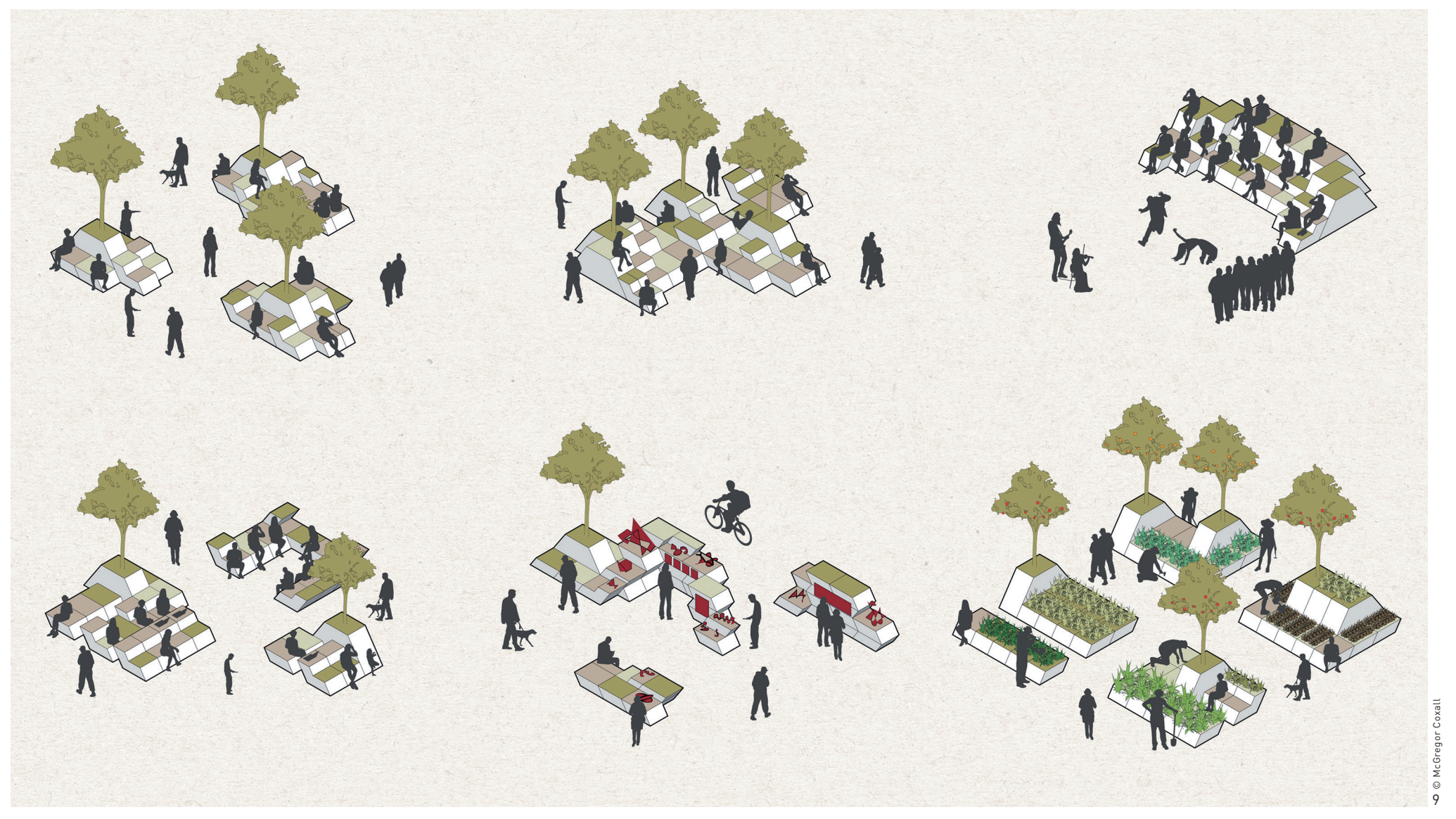


9. “会呼吸的房间” 项目 基本模块可组成各种各 样的开放空间

10. “会呼吸的房间”项目 预景

Modules of Breathing Rooms creating various open spaces

10. Scenario of Breathing Rooms

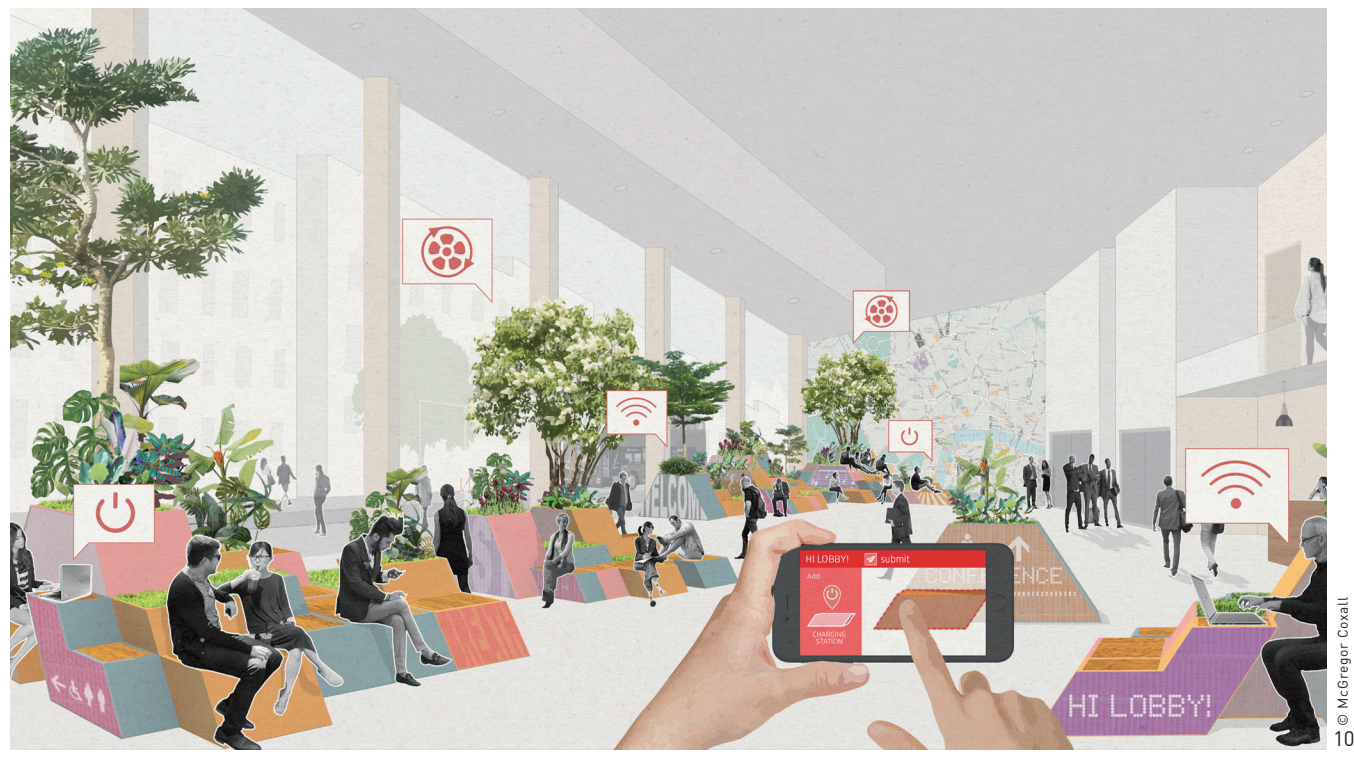

neutral, mainly vacant spaces to actively perform as part of the urban fabric, environmentally, socially, and culturally. an intelligent multi-functional system supporting energy production, lighting displays, sensory recognition, and live analytics. A prototype will be installed at the London Festival of Architecture 2018.

"Hi Croydon!" is a series of adaptable components to create social infrastructure: furniture, signage, planting, etc. The elements are coupled with an augmented reality application that allows the community to design their own public spaces. Targeting both social and environmental sustainability, each unique deployment will be built around the character of its specific location and the inputs of different community groups. The project is now in development with Croydon City Council.

"Breathing Rooms" looks at the corporate lobby as a unique spatial environment where to trial strategies for future buildings. Expanding green networks, streets, and public spaces, the initiative would allow previously

\section{Summary}

The projects illustrated here are only a few examples of how McGregor Coxall integrates a deep-seated understanding of natural ecosystems and their requirements with existing and emerging modes of urban and regional development. The challenge for us (and all practitioners working in and on the city) is how to reconcile and integrate these natural and manmade ecosystems into an integrated whole, harmonising with their urban context.

We aim to understand the city and its systems and inhabitants in all their complexity and, by doing so, to discover hidden assets and latent demands. From these discoveries, we formulate networks of connectivity and communication to create opportunities, whether spatial, informational, social, environmental, economic, or cultural.
In the process, we allow comprehensive engagement into, interaction with, and ownership of all aspects of our projects (whether public spaces, parks, urban precincts, streets, backyards, regional economies, or national ecosystems) by all stakeholders and residents, from the oldest to the youngest.

For all of our projects, McGregor Coxall and our collaborators establish clear strategic frameworks for implementing these objectives, including the project's development over time, as the needs and resources of the city, the government, the community, and all stakeholders evolved and expand. The McGregor Coxall team's approach to each of our projects creates a vision for that place and its surroundings based on what it was, appreciative of what it is, and imagining what it could be, all the while understanding that every place is, and has always been, a unique place, at the intersection of land and water, landscape and city, and each a potential center of a vibrant and productive community. LAF 